\title{
Etika komunikasi Islam mahasiswa organisasi PMII (Pergerakan Mahasiswa Islam Indonesia) dalam menangkal berita hoaks di Facebook
}

\author{
Ila Khafia Wafda ${ }^{1 *}$ \\ ${ }^{1}$ UIN Walisongo Semarang
}

\begin{abstract}
This study aims to see how Islamic communication ethics is in an effort to ward off hoax news on Facebook that hit students of the PMII. The reason is, the existence of hoax reporting on Facebook contradicts the vision of the PMII organization which is committed to being a forum for strengthening aqidah, morals, and creating a society like the Ummah. The research used qualitative research methods through in-depth interview approaches and observations of active students in the PMII organization, uses a sampling technique based on purposive sampling technique. The results showed that students instilled communication ethics according to Islamic law in using Facebook social media, so steps need to be taken to communicate in accordance with Islamic teachings to avoid the rampant hoax news on Facebook to promote morals according to Islamic law refer to the example of the Prophet, p.b.u.h. That it is important for PMIl student organizations to promote morals in accordance with Islamic law, and also apply communication ethics in accordance with Islamic law by promoting the principles of Islamic communication, namely: qawlan sadidan, qawlan balighan, qawlan maysura, qawlan layyina, qawlan karima, qawlan ma'rufa. So it is necessary to understand and apply Islamic communication ethics by students of the PMII organization, so that it becomes the basis for accessing Facebook.
\end{abstract}

Keyword : ethics, facebook, islamic communication

\begin{abstract}
Abstrak: Penelitian ini bertujuan untuk mengetahui bagaimana etika komunikasi Islam dalam upaya untuk menangkal pemberitaan hoaks di Facebook yang menerpa mahasiswa organisasi PMII (Pergerakan Mahasiswa Islam Indonesia). Karena keberadaan pemberitaan hoaks di facebook bertolak belakang dengan visi organisasi PMII yang memiliki komitmen sebagai wadah pemantapan aqidah, akhlak karimah, dan mewujudkan masyarakat yang khoiru ummah. Penelitian ini menggunakan metode penelitian kualitatif melalui pendekatan metode wawancara mendalam dan observasi terhadap mahasiswa yang aktif dalam organisasi PMII. Penelitian ini dengan menggunakan teknik sampling yang dilakukan berdasarkan teknik purposive sampling. Hasil penelitian bahwa mahasiswa menanamkan etika komunikasi sesuai syari'at Islam dalam menggunakan media sosial Facebook, maka perlu dilakukan langkah-langkah berkomunikasi yang sesuai dengan ajaran Islam agar terhindar dari maraknya berita hoaks di Facebook untuk mengedepankan akhlakul karimah sesuai syari'at Islam yang sudah diajarkan Rasulullah saw. Bahwasannya penting bagi mahasiswa organisasi PMII untuk mengedepankan akhlak sesuai dengan syari'at Islam. Selain itu mahasiswa organisasi PMII juga menerapkan etika komunikasi sesuai syari'at Islam dengan mengedepankan prinsip
\end{abstract}

"Corresponding Author: Ila Khafia Wafda | ilakwafda@gmail.com| Universitas Islam Negeri (UIN) Walisongo, JI. Prof. Dr. Hamka, Ngaliyan, Semarang, Indonesia. 
komunikasi Islam, yaitu: qawlan sadidan, qawlan balighan, qawlan maysura, qawlan layyina, qawlan karima, qawlan ma'rufa. Sehingga perlunya pemahaman dan penerapan etika komunikasi Islam oleh mahasiswa organisasi PMII, agar menjadi pondasi dalam mengakses Facebook.

Kata Kunci: etika, facebook, komunikasi islam

\section{Pendahuluan}

Berdasarkan databooks penduduk Indonesia beragama Islam pada tahun 2020, diperkirakan mencapai 229,62 juta jiwa. Sehingga negara Indonesia disebut sebagai Negara dengan penduduk muslim tersebar di dunia (Kusnandar, 25/9/2019, 11.00 WIB, Indonesia, Negara dengan Penduduk Muslim Terbesar di Dunia, Dikutip dari

https://databoks.katadata.co.id/datapu blish/2019/09/25/indonesia-negaradengan-penduduk-muslim-terbesardunia). Seharusnya masyarakat Indonesia, khususnya muslim berpegang dengan nilai-nilai etika Islam dalam berkomunikasi. Terdapat beberapa persoalan pada saat berkomunikasi, seperti halnya menjelek-jelekan orang lain melalui media sosial.

Ditemukan kasus, seorang dokter perempuan yang bernama Siti sundari Dara Nila Utama yang terjerat hukuman pidana, karena menuliskan komentar dan status yang bernada SARA kepada panglima TNI, Marsekal Hadi Tjahjanto. Tersangka menyebarkan berita hoaks melalui akun Facebook Gusti Sikumbang, maka ia yang berprofesi sebagai dokter tersebut ditangkap pada 15 Desember 2017. Setelah dicek oleh pihak kepolisian di dalam akun pribadinya juga ditemukan sejumlah unggahan menyinggung SARA. Akhirnya dengan kasus ini Sundari dikenakan UU Nomor 19 Tahun 2016 tentang Informasi transaksi Elektronik dan UU 40 tahun 2008 Tentang Penghapusan Diskriminasi Ras dan Etnis, Ia terancam hukuman penjara enam tahun (Andi Saputra, DetikNews, 01/04/2019, 16.09 WIB, Ternyata MA Sunat Hukuman Dokter Wanita yang Fitnah Panglima TNI, Dikutp dari https://news.detik.com/berita/d4492567/ternyata-ma-sunathukuman-dokter-wanita-yang-fitnahpanglima-tni).

Aksi menyinggung SARA atau menyebarkan pemberitaan tidak benar ini dengan bahasa populer yang biasa disebut hoaks. Berita hoaks suatu fenomena yang santer menggencarkan jagad maya, seperti berita yang tersebar melalui media sosial dengan konten-konten berita dan informasi yang tidak benar tersebut dapat menimbulkan perselisihan dan pertentangan.

Berdasarkan riset DailySosial.id pada 2018 terdapat 44\% masyarakat Indonesia tidak bisa mendeteksi berita hoaks yang tersebar di internet. Saluran terbanyak penyebaran informasi hoaks di media sosial banyak ditemukan di platform Facebook (82,25\%), WhatsApp (56,55\%), dan Instagram (29,48\%). Banyak responden $(44,19 \%)$ tidak 
yakin memiliki kepiawaiannya dalam mendeteksi berita hoaks. Mayoritas responden $(51,03 \%)$ memilih berdiam diri untuk tidak percaya dengan adanya informasi ketika menemui berita hoaks. Namun terdapat sekitar $72 \%$ responden memiliki kecenderungan untuk membagikan informasi yang mereka anggap penting. Sebagian besar responden (73\%) selalu membaca seluruh informasi. Namun hanya sekitar setengah $(55 \%)$ yang selalu memverifikasi keakuratan (fact check) informasi (Rika Eka, 16/8/2018, Facebook, WhatsApp, dan Instagram adalah platform yang paling digunakan untuk menyebar hoaks, Dikutip dari https://dailysocial.id/post/laporandailysocial-distribusi-hoax-di-mediasosial-2018). Berdasarkan riset terlihat bahwa berita hoaks yang dibagikan melalui media sosial paling banyak terdapat dari platform Facebook.

Kurangnya penyaringan akan informasi berita di media sosial terutama melalui Facebook dari pihak yang berwenang semakin memudahkan para pembuat dan penyebar hoaks dalam melakukan aksinya. Sehingga membuat berita hoaks, fitnah, ujaran kebencian, hujatan bermunculan tanpa henti di media sosial, seperti pada Pilkada tahun 2018 yang diwarnai dengan banyaknya kampanye hitam dan berita bohong atau hoaks melalui media sosial sebagai alat untuk menjatuhkan lawan politik dengan cara membuat opini yang menyesatkan agar masyarakat percaya dan terjebak dengan informasi dalam hoaks tersebut (Septanto, 2018).

Informasi pemberitaan dari media internet pada awal tahun 2020 telah dihebohkan dengan adanya penyebaran virus corona di Wuhan China. Banyaknya pemberitaan yang tersebar sangat menggemparkan media sosial dan internet. Adapun pihak-pihak yang tidak bertanggung jawab memanfaatkan hal tersebut, dengan menyebarkan pemberitaan hoaks tentang virus corona. Banyak muncul berita hoaks termasuk informasi yang salah dan saran yang tidak akurat melalui internet dan media sosial. Hingga Menteri Komunikasi dan Informatika (Kominfo) Johny G. Plate menjelaskan bahwa pemerintah akan terus menghimbau kepada masyarakat, untuk menyaring informasi melalui internet dan media sosial. Kominfo menegaskan bagi siapapun yang menyebarkan informasi hoaks akan terancam sanksi sesuai ketentuan yang termaktub dalam Undang-undang Pasal 28 Ayat 1 UU No 11 Tahun 2008 tentang UU ITE yang saat ini telah diubah menjadi UU No. 19 tahun 2016 (Wahyunanda Kusuma Pertiwi, Kominfo Identifikasi 54 Hoaks Virus Corona, Penyebar Bisa Dijerat UU ITE, 03/02/2020, 13:39 WIB, Dikutip dari

https://tekno.kompas.com/read/2020/ 02/03/13394877/kominfoidentifikasi-54-hoaks-virus-coronapenyebar-bisa-dijerat-uuite?page $=$ all). 
Penyebaran berita hoaks yang berujung fitnah melalui media sosial khususnya Facebook semakin meluas, sebab jika terus dibiarkan akan menimbulkan perdebatan. Sebab jika penyebaran informasi mengandung hal negatif, apabila terus dibiarkan dikhawatirkan akan membahayakan generasi muda. Penikmat media sosial Facebook dari kalangan anak muda, salah satu penggunanya adalah mahasiswa, karena ada umumnya mahasiswa menjadikan media sosial Facebook sebagai sarana komunikasi, untuk mencari informasi dan hiburan.

Salah satu yang menjadi sorotan utama dalam tulisan ini adalah untuk mengetahui bagaimana penerapan etika komunikasi terhadap dampak negatif keberadaan Facebook bagi mahasiswa organisasi PMII. Karena organisasi PMII sebagai wadah bagi generasi muda untuk membangun identitas diri mahasiswa memiliki nilai-nilai keislaman dan siap mengamalkan ilmu dengan penuh tanggung jawab.

Berikut ini beberapa faktor yang mempengaruhi kemampuan mahasiswa dalam menilai berita palsu (hoaks) antara lain: faktor emosional terhadap situasi sebuah kejadian, faktor mudahnya terpengaruh dan faktor keterbatasan kemampuan dalam menguji kebenaran (Fatkhurahman, 2018). Secara psikologis salah satu faktor yang masih tinggi ialah faktor tingkat emosional yang ada pada diri remaja, penikmat media sosial paling banyak adalah generasi muda. Berdasarkan permasalahan tersebut, maka penelitian ini akan membahas mengenai etika komunikasi Islam dalam menangkal fenomena berita isa disusun ulang pencegahan berita hoaks di media sosial Facebook. Berdasarkan penulisan ini untuk mengkaji, bagaimana mahasiswa organisasi PMII (Pergerakan Mahasiswa Islam Indonesia) menciptakan etika komunikasi yang baik dalam menangkal berita hoaks di Facebook?.

\section{Metode}

Penelitian ini menggunakan pendekatan metode kualitatif, yaitu dengan menghasilkan data deskriptif yang berupa kata-kata yang tertulis maupun lisan melalui fenomena sosial dan masalah manusia. Teknik pengumpulan data dilakukan dengan studi di lapangan melalui observasi dan wawancara dengan para mahasiwa organisasi Islam PMII di Universitas Islam Sultan Agung, ketika melihat fenomena beredarnya berita hoaks yang semakin tinggi di media sosial Facebook secara purposive sampling, yaitu dengan mengambil informan dilakukan secara acak atas pertimbanganpertimbangan tertentu yang ditetapkan oleh peneliti. Selain melalui wawancara, juga menggunakan observasi dalam pengumpulan data. Metode analisa data yang digunakan yaitu metode deskriptif, dimana dengan mendeskripsikan hasil data yang sudah diperoleh melalui responden dan informan secara tertulis atau yang dipelajari dan diteliti sebagai suatu 
kesatuan yang utuh dengan penelitian ini. Sehingga, dengan demikian diharapkan dapat menghasilkan analisis yang mampu menjawab permasalahan yang sudah dirumuskan.

\section{Kerangka teori}

Etika Komunikasi Islam

Etika dipandang sebagai istilah dari segi etimologi yang berasal dari kata Latin ethica, yang berarti kebiasaan. Sesuatu yang dipandang etis atau baik, apabila sesuai dengan kebiasaan masyarakat. Berdasarkan bahasa Yunani etika disebut ethos. Kata yang berbentuk tunggal ini berarti “adat atau kebiasaan". Pengertian lain tentang etika ialah sebagai studi atau ilmu yang membicarakan perbuatan atau tingkah laku manusia, yang mana akan dinilai dan mana pula dinilai buruk. Etika juga disebut ilmu normatif, maka dengan sendirinya berisi ketentuan-ketentuan yang dapat digunakan sebagai acuan untuk menilai tingkah laku yang baik atau buruk (Mutiah et al., 2019).

Etika dan moral memiliki sebuah arti yang sama, namun terdapat sedikit perbedaan dalam pemakaian seharihari, di mana moral dipakai untuk perbuatan yang sedang dinilai atau dikaji, sedangkan etika dipakai untuk pengkajian sistem nilai yang ada dalam kelompok atau masyarakat tertentu (Erni R. Ernawan, 2011). Sebagai makhluk sosial, kita harus mengetahui bahwa etika adalah hal yang mendasar dalam kehidupan manusia. Terlebih lagi kita sebagai orang Indonesia yang sedari kecil sudah biasa diajari tentang sopan santun, tata krama, dan adat kebiasaan. Etika tidak dapat dipisahkan dari komunikasi, keduanya saling berkaitan. Ketika melakukan komunikasi yang baik tentu saja tidak bisa dipisahkan dengan adanya suatu etika. Komunikasi dari segi bahasa, kata komunikasi berasal dari bahasa Latin communis, yang artinya "membuat kebersamaan" atau "membangun kebersamaan antara dua orang atau lebih". Akar kata communis merupakan communico, yang memiliki arti "berbagi" (Soyomukti, 2010).

Pandangan manusia saat melakukan suatu penilaian terhadap perilaku orang lain dapat dilihat melalui etika dalam berkomunikasi. Etika menurut Drs. D. P. Simorangkir adalah pandangan manusia pada saat berperilaku sesuai dengan ukuran dan nilai yang baik (M. Rakhmat, 2013). Suatu etika didukung oleh beberapa nilai dalam kehidupan sosial antara lain: (1) Nilai-nilai kepentingan umum (2) Nilai-nilai kejujuran, keterbukaan dan kebaikan (3) Nilainilai kesejahteraan (4) Nilai-nilai kesopanan, harga menghargai (5) Nilai-nilai dengan pertimbangan rasional yang mampu membedakan sesuatu dengan sifat rahasia dan yang bukan rahasia (Purnama, 2017).

Kehidupan sosial dalam hubungan seseorang dengan orang lain terjadi proses komunikasi. Tetapi ketika sedang melakukan komunikasi terkadang tidak memperhatikan etika komunikasi dengan baik. Proses dalam menyampaikan pesan dari komunikator kepada komunikasi 
merupakan hakikat dan peranan etika dalam berkomunikasi, agar maksud dan tujuannya dapat tersampaikan. Hal ini agar pesan komunikasi yang ingin disampaikan memiliki kesamaan makna baik dari komunikator maupun komunikan (Mannan, 2019).

Adanya komunikasi, membuat manusia mengekspresikan dirinya, dengan membentuk jaringan interaksi sosial, dan mengembangkan kepribadiannya. Suatu komunikasi mengalami kegagalan yang fatal, maka akan menghambat saling pengertian, menghambat kerja sama, menghambat toleransi, dan merintangi pelaksanaan norma-norma sosial (Muslimah, 2016).

Perkembangan etika komunikasi berkembang sesuai dengan dinamika masyarakat yang ada. Sehingga etika komunikasi menjadi sangat penting dalam kehidupan sosial. Sebab etika komunikasi merupakan ilmu yang mempelajari baik buruknya tentang hak dan kewajiban moral (akhlak) dalam berkomunikasi. Etika komunikasi mengutamakan kejujuran, keharmonisan hubungan, pesan yang tepat dan menghindari adanya kecurangan (Prasanti \& Indriani, 2017). Etika komunikasi di media sosial dibagi atas tiga poin penting, yaitu etika dalam konteks waktu; etika dalam konteks isi pesan; etika dalam konteks komunikan (Afriani \& Azmi, 2020). Berikut adalah beberapa macam etika yang perlu diperhatikan saat berkomunikasi di media sosial:

1) Selalu perhatikan penggunaan kalimat
2) Berhati-hati dalam menggunakan huruf

3) Perhatikan pemilihan warna huruf

4) Pemilihan simbol dan ikon yang tepat

5) Menggunakan bahasa yang sesuai

6) Memberikan respon dengan segera

7) Memberikan informasi yang memiliki referensi jelas

8) Tidak memancing pertentangan (Muhammad Syu'aib Taher, 2019).

9) Sedangkan etika komunikasi Islam adalah aktifitas komunikasi yang nilai-nilainya bersumber dari pokok ajaran Islam (Kholil, 2007).

Etika komunikasi Islam adalah suatu bentuk komunikasi yang sesuai dengan tuntunan al-Qur'an dan asSunnah, sehingga komunikator yang memuat content (isi pesan) secara islami (sesuai dengan ajaran agama Islam), diharapkan akan menghasilkan komunikasi yang beretika atau berakhlakul karimah. Proses aktifitas etika komunikasi sangat penting, sebab etika sebagai standar nilai yang harus dijadikan acuan dalam berprilaku, bertindak dan berbuat. Secara sederhana orang yang tidak paham dan patuh oleh aturan yang berlaku maka akan dinilai tidak mempunya etika dalam tindak tanduknya. Sebaliknya, orang yang senantiasa tunduk kepada norma yang berlaku dapat dikatakan orang yang mempunyai etika. Maka seorang komunikan harus mempunyai etika yang baik dan komunikasi yang 
baik terlebih dahulu sebagai pendukungnya. Semua proses komunikasi yang Islami harus terikat pada norma-norma agama Islam, dengan kata lain komunikasi menurut ajaran Islam sangat memuliakan etika yang dibarengi dengan sangsi akhirat (Mannan, 2019).

Pada umumnya ajaran Islam dibagi menjadi tiga aspek. Pertama ajaran tentang akidah yang membicarakan tentang keyakinan-keyakinan, berkaitan dengan rukun iman. Kedua, syari'ah yang menyangkut masalah hukum Islam biasa disebut dengan fiqh. Ketiga, akhlak yaitu ajaran Islam yang terkait dengan masalah-masalah ajaran moral. Dalam hal ini seorang ulama dan intelektual muslim Hamka memiliki pandangan yang berbeda tentang ajaran Islam ini. Menurutnya inti ajaran Islam adalah tauhid. Sedangkan akhlak atau etika berada dalam urutan kedua setelah ajaran inti atau tauhid. Syari'ah justru menempati urutan ketiga dari ajaran inti tauhid. Baru setelah syariah inilah ajaranajaran yang terkait dengan masalahmasalah sosial lainnya (Haris, 2010).

Etika komunikasi dalam perspektif Islam dapat distandarkan kepada temuan terhadap perkataan atau perbuatan yang baik dapat ditemukan sesuai dengan syariat Islam yaitu tertera dalam Al-Qur'an. Menurut Dahlan dan Syihabuddin term-term pola komunikasi yang dapat dikategorikan sebagai bentuk etika komunikasi sesuai syariat Islam yaitu tertera di dalam Al-Qur'an tersebut ditemukan sebagai berikut:
Pola qawlan baligha perkataan yang membekas pada jiwa, tepat sasaran, komunikatif, mudah dimengerti, ungkapan ini ditemukan dalam QS. An-Nisa (4): Ayat 63;

Pola qawlan karima diterjemahkan dengan perkataan yang mulia, terdapat dalam QS. Al-Isra' (17): 23;

Pola qawlan masyura diterjemahkan dengan perkataan yang ringan atau mudah dimengerti, terdapat dalam QS. Al-Isra' (17): 28;

Pola qawlan ma'rufa diterjemahkan dengan perkataan yang baik, terdapat dalam QS. Al-Ahzab (33): 32;

Pola qawlan layyina diterjemahkan dengan perkataan yang lemah lembut, terdapat dalam QS. AtTaha (20): 44;

Pola qawlan sadida diterjemahkan dengan perkataan yang benar, lurus dan jujur, terdapat dalam QS. An-Nisa' (4) Ayat 9, QS. AlAhzab (33): 70; (Muslimah, 2016).

Menurut A. Muis dalam bukunya Komunikasi Islam, pada dasarnya yang membedakan antara komunikasi Islam dengan komunikasi non-Islam terletak pada model, proses dan efeknya, namun yang membedakan lebih kepada landasan filosofinya. Jika filosofi komunikasi Islam berlandaskan pada Al-Qur'an dan Hadis Nabi. Jadi proses penyampaian pesan komunikasi Islam didasarkan pada ajaran agama Islam yang terkandung dalam Al-Qur'an dan Hadis. Proses penyampaian pesan etika komunikasi Islam kurang lebih 
sama dengan etika komunikasi umum, untuk isi perintah dan larangan sama atau serupa antara keduanya. Hanya saja yang membedakan antara keduanya terletak pada sanksi dan pahalanya. Komunikasi umum (non-Islam) memang lebih mementingkan etika, tetapi sanksi atas pelanggaran komunikator terhadap etika komunikasi hanya berlaku di dunia. Sedangkan etika komunikasi Islam untuk sanksi atas pelanggarannya berlaku sampai akhirat (Muis, 2001).

Berdasarkan hal di atas dapat disimpulkan etika komunikasi sesuai dengan ajaran agama Islam hendaknya selalu diterapkan dalam berbagai bentuk kegiatan sehari-hari. Etika komunikasi merupakan sebagai tata cara berkomunikasi yang sesuai dengan standar nilai moral atau akhlak dalam menilai benar salah perilaku individu atau kelompok. Sehingga jika dihubungkan dengan Islam, maka etika tersebut berdasarkan petunjuk yang diisyaratkan oleh Al-Qur'an dan AsSunnah yang menjadi pedoman hidup bagi agama Islam. Jadi dengan adanya etika itu, maka secara tidak langsung menunjukkan perlunya belajar sebelum memulai komunikasi, agar komunikasi dapat berjalan dengan baik dan lancar (Ariani, 2015).

Hal ini dimaksudkan untuk mendatangkan suatu kebaikan dan keselamatan serta kebahagiaan bagi kehidupan umat manusia.

\section{Hoaks}

New media (media baru) saat ini mengalami perkembangan yang pesat, sehingga para penggunanya semakin banyak terlebih bagi para mahasiswa. Mahasiswa sebagai generasi milenial menempati peringkat pertama dalam penggunaan media internet. Usia remaja merupakan usia menginjak perguruan tinggi, di mana media menjadi sangat penting untuk digunakan sebagai perpustakaan maya, untuk mencari informasi dan pengetahuan yang berhubungan dengan perkuliahan bersumber pada media online. Seperti yang terlihat pada tabel 2 sebagai berikut:

Tabel 2

Deskripsi Frekuensi Pengguna Media Online Mahasiswa

\begin{tabular}{|l|c|c|c|}
\hline No & Kategori & F & \% \\
\hline 1. & $\begin{array}{c}\text { Heavy User }(>40 \\
\text { jam perbulan })\end{array}$ & 170 & 69.7 \\
\hline 2. & $\begin{array}{c}\text { Middle User }(10- \\
\text { 40 jam pebulan) }\end{array}$ & 40 & 16.4 \\
\hline 3. & $\begin{array}{c}\text { Light User }(<10 \\
\text { jam perbulan })\end{array}$ & 34 & 13.9 \\
\hline & Jumlah & $\mathbf{2 4 4}$ & $\mathbf{1 0 0}$ \\
\hline
\end{tabular}

Berdasarkan Tabel di atas dapat disimpulkan bahwa sebagian besar Mahasiswa frekuensi pemanfaatan media online berada pada kategori heavy user yang merupakan pemanfaatan internet dengan menghabiskan waktu lebih dari 40 jam perbulannya, dengan presentase sebesar $69.7 \%$. Sedangkan middle user merupakan pemanfaatan internet dengan menghabiskan waktu kisaran 10 sampai 40 jam per bulan, dengan jumlah $16.4 \%$. light user hanya 10 
jam per bulannya dalam penggunaan internet, dengan presentase $13.9 \%$. Kesimpulannya bahwa pengguna media internet pada mahasiswa berada pada frekuensi tinggi dengan pengguna lebih dari 40 jam perbulan (Walidaini, 2018: 43). Dunia pendidikan adalah satu bidang yang banyak memanfaatkan media online untuk kepentingan peningkatan kualitas suatu institusi pendidikan. Pendidikan memang pemegang peran penting dalam kemajuan suatu bangsa dan negara, karena dunia pendidikan mencetak para generasi penerus bangsa. Adanya media online membuka ruang lebar bagi kehadiran informasi atau berita-berita bohong (hoaks) tentang suatu peristiwa yang bisa juga meresahkan publik.

Hoaks adalah "decide somebody with a hoaks" (memperdaya seseorang dengan sebuah berita yang bohong atau tidak benar) (Oxford University Press, 2011). Penyebaran hoaks ini tidak akan lepas dari dukungan media massa, baik media cetak maupun media elektronik. Sedangkan dalam bentuk kata benda, hoaks diartikan sebagai "trick played on somebody for a joke" (bermain tipu muslihat dengan orang lain untuk sesuatu yang bercanda) atau "anything deliberately intended to deceive or trick" (apapun yang dengan sengaja dimaksudkan atau ditujukan guna untuk menipu orang lain) (Maulana, 2017). Hoaks dalam istilah bahasa indonesia merupakan suatu pemberitaan palsu atau bohong.

Hoaks menurut Bungin (2017), meskipun memiliki "masa hidup" dalam kognitif lebih pendek dari pada konstruksi sosial media massa, namun hoaks memiliki daya rusak sporadik yang kuat dan luas di masyarakat. Jadi, hoaks merupakan salah satu persoalan serius dalam etika komunikasi karena dapat merusak citra lawan. Semua berita hoaks tidak saja merugikan subjek hoaks namun juga menyerang dan merusak tatanan etika di masyarakat, bahkan dapat menjadi mesin pertumbuhan karakter seseorang. Karena itu beberapa upaya antisipasi penyebaran berita hoaks harus dilakukan (Juditha, 2018).

Fenomena berita hoaks sudah ada sejak zaman dahulu sebagaimana dalam QS. An-Nur ayat 11. Menurut sebuah riwayat, munculnya ayat tersebut tidak lain karena adanya tuduhan zina yang ditujukan kepada Aisyah ketika ia akan pulang menuju Madinah bersama pasukan Muslimin. Cerita Aisyah mencari kalungnya yang hilang, kemudian tidak sengaja bertemu sabahatnya bernama Safwan bin al-Mu'attal Al-Sulami AlDhakwani dan mereka pulang bersama. Setelah peristiwa tersebut beberapa dari umat Islam malah ramai membicarakan dan menyebarkan berita bohong tentang Aisyah hingga selama sebulan Aisyah merasakan ada yang beda dari Rasulullah Saw dalam menyikapinya, bahkan hendak mendiskusikan untuk menceraikan Aisyah atas hal ini. Aisyah terus mengeluh dan mengadu kepada Allah SWT tentang apa yang telah terjadi, hingga turunlah QS. An-Nur 24: 11 yang menjawab kegelisahannya (Maulana, 2017):“'Sesungguhnya 
orang-orang yang membawa berita bohong adalah golongan kamu, janganlah kamu menganggap buruk bagi kamu, bahkan ia adalah baik bagi kamu, dari tiap-tiap orang akan memperoleh dosa atas apa yang mereka kerjakan, dan siapa yang mengambil bagian yang terbesar di dalamnya di antara mereka, bagian azab yang besar" (QS. An-Nur 24: 11) (Kementerian Agama RI, 2011).

Terdapat dalam perjalanan sejarah Islam, yang tak lain pemberitaan hoaks pada masa Siti Maryam ibu Nabi Isa yang dituduh berbuat keji, sehingga melahirkan anak tanpa adanya seorang bapak. Hingga pada akhirnya Allah mengklarifikasi tuduhan tersebut terhadap Maryam dengan turunnya sebuah wahyu yang telah dijelaskan dalam Al-Qur'an surat Maryam ayat 28: "Hai saudara perempuan Haruan, ayahmu sekali-kali bukanlah seorang yang jahat dan ibumu sekali-kali bukanlah seorang pezina" (Kementerian Agama RI, 2011). Kisah di atas merupakan sejarah hoaks perjalanan manusia di jaman Rasul, hingga kemudian ada pada generasi selanjutnya seperti sekarang ini di era global.

Jenis-jenis informasi hoaks berdasarkan data yang dikumpulkan oleh Rahardi terdiri dari tujuh jenis yaitu:

1. Fake news, berusaha untuk menggantikan berita bohong dengan berita yang asli. Usaha tersebut bertujuan untuk memalsukan kebenaran dalam suatu berita. Pada berita fake news tersebut biasamya ditambahkan dengan hal-hal yang tidak benar dan teori persekongkolan, makin aneh, makin menarik.

2. Clickbait, merupakan jenis hoaks datang tiba-tibatautan yang diletakkan secara strategis di dalam suatu situs dengan tujuan untuk menarik perhatian orang agar masuk ke situs lainnya.

3. Confirmation bias, yaitu kecenderungan untuk menginterpretasikan kejadian yang baru terjadi sebagai bukti dari kepercayaan yang sudah ada.

4. Misinformation, informasi yang salah atau tidak akurat terutama yang ditujukan untuk menipu.

5. Satire, sebuah tulisan yang menggunakan humor, ironi, halhal yang dibesar-besarkan untuk mengomentari kejadian yang sedang hangat.

6. Post-truth, kejadian di mana emosi lebih berperan daripada fakta untuk membentuk opini publik.

7. Propaganda atau aktifitas menyebarluaskan informasi, fakta, argument, gosip. Setengah kebenarannya atau bahkan kebohongan untuk mempengaruhi opini publik (Ulya, 2018).

Berdasarkan data BPS tahun 2013 yang sudah dikeluarkan, bahwa ditahun 2015 jumlah millennial dari total penduduk Indonesia diperkirakan mencapai 33\%. Artinya, total populasi millennial ada pada 
usia 20 hingga 40 tahun dapat mencapai 34\%. Pada tahun tersebut generasi milenial menjadi inovator, mereka mengandalkan teknologi untuk belajar dan bekerja di dalam lingkungan inovasi, sehingga membuat mereka melakukan perubahan di dalam berbagai aspek kehidupannya (Walidah, 2018). Hasanuddin Ali dan Lilik Purwandi menyimpulkan bahwa masyarakat Urban Middle Class Millennial memiliki tiga karakter utama (3C), diantaranya; Pertama, connected merupakan generasi milenial adalah pribadi yang mempunyai kepandaian dalam bersosialisasi di media sosial. Kedua, creative merupakan mereka yang mempunyai pemikiran out of the box, kaya akan ide serta gagasan dan mempunyai kemampuan untuk mengkomunikasikannya secara cemerlang yang dibuktikan dengan tumbuhnya industri yang dimotori oleh anak muda. Ketiga, confidence merupakan mereka yang mempunyai percaya diri tinggi dengan mampu mengungkapkan pendapat, serta tidak sungkan untuk berdebat di depan publik, seperti halnya yang terjadi di media sosial (Ali et al., 2017).

\section{Hasil dan pembahasan}

Fenomena berita hoaks menurut mahasiswa organisasi pmii

Perkembangan internet membawa cara baru bagi masyarakat dalam berkomunikasi. Penggunaan media sosial memberikan kemudahan dalam berkomunikasi. Sebab dengan mudah dalam mengirimkan dan mengakses informasi yang dibutuhkan. Hadirnya media sosial Facebook bisa mempertemukan teman atau keluarga yang sudah lama tidak bertemu, karena faktor jarak. Media sosial Facebook juga dapat digunakan sebagai media untuk saling berbagi informasi, bertukar foto, data serta dokumen lainnya. Bagi kawula muda media sosial Facebook biasanya dimanfaatkan sebagai sarana bertukar informasi, termasuk yang berkaitan dengan kegiatan organisasi, khususnya bagi mahasiswa yang aktif dalam Organisasi Islam PMII. Media sosial sebagai sarana memudahkan penggunanya untuk membagikan informasi yang berupa pendidikan, media berdiskusi dan sebagai fasilitas dalam mengemukakan pendapat. Namun pada kenyataannya bukan dipergunakan sesuai dengan fungsinya, melainkan disalahgunakan dengan menyebarkan isu yang tidak benar. Begitu pula dengan adanya kemudahan yang diperoleh, justru membawa dampak yang serius. Sebab rata-rata di media sosial, memiliki fitur share, like, repost atau sejenisnya yang memudahkan penggunanya untuk membagikan konten yang akan disebarkan. Sehingga media sosial merupakan wadah yang subur untuk tumbuhnya informasi hoaks.

Hasil survey Mastel (masyarakat telematika Indonesia) tahun 2019, pemaknaan hoaks berdasarkan pemikiran masyarakat terdapat $88 \%$ yang mengatakan bahwa hoaks merupakan berita bohong yang 
disengaja. Dapat dilihat dari data di bawah ini: (Mastel, 2019)

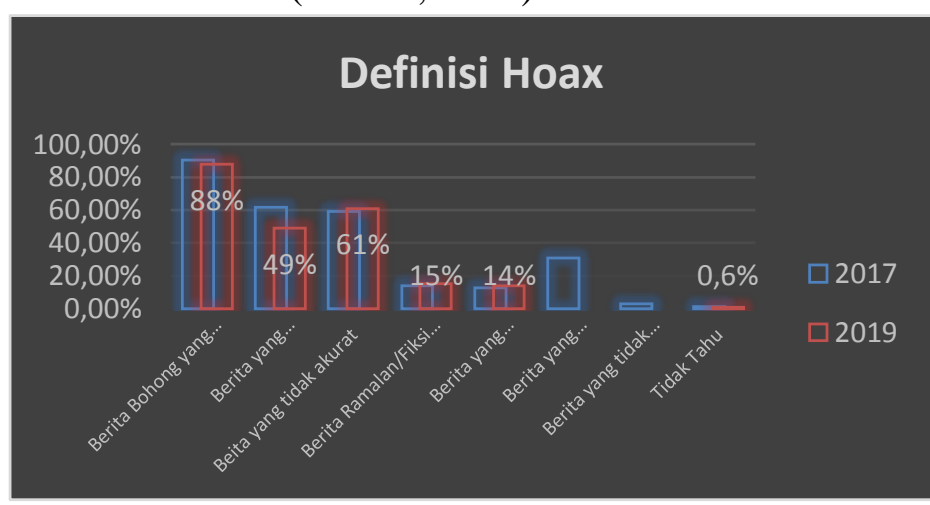

Dari definisi tersebut, berita hoaks memiliki dampak yang merugikan para pembacanya. Sehingga dapat menimbulkan fitnah atau kesalahpahaman, karena berita tersebut tidak benar. Apalagi sekarang sulit sekali untuk membedakan berita yang benar dan berita yang palsu. Berita hoaks sudah mendarah daging penyebarannya di media sosial yang membuat anakanak remaja, khususnya mahasiswa masih belum mengetahui perbedaan berita fakta atau hoaks. Sekarang ini sangat sulit untuk membedakan apakah berita tersebut fakta ataupun hoaks.

Berikut ini hasil wawancara dengan beberapa narasumber tentang bahaya hoaks:

1. "Menurut saya hoaks ya berita tidak benar tapi dibuat benar, berita hoaks ini sangat merugikan orang lain soalnya jatuhnya itu fitnah. Informasi yang ada pada berita hoaks rata-rata hanya menilai seseorang secara sepihak saja tanpa mengetahui kebenarannya. Dilansir dari situs Wikipedia berita palsu atau berita bohong atau biasa disebut dengan hoaks merupakan suatu informasi yang tidak benar adanya, namun biasanya ya dibuat seolah-olah benar adanya." (Hasil wawancara dengan Dewi pada tanggal 13 Juli 2020);

2. "Biasanya berita hoaks sama saja dengan berita bohong yang dibuat dan diedarkan secara asal-asalan tanpa adanya unsur kebenaran, ditakutkan muncul sikap-sikap yang tidak diinginkan bagi yang kurang imannya." (Hasil wawancara dengan Rika pada tanggal 13 Juli 2020);

3. "Banyak orang yang mengambil keuntungan dari berita hoaks, sehingga di zaman sekarang tidak mudah membedakan antara berita hoax dan fakta. Karena mungkin terlalu percaya terhadap informasi yang tersebar luas di media sosial. Untuk pengaruhnya, lebih dominan terhadap sudut pandang yang mengkonsumsi, dan lebih fatal jika diterapkan ke dalam kehidupan, apalagi untuk anak usia remaja seperti saya. Selain itu, hoaks juga akan menimbulkan fitnah dan citra yang tidak baik." (Hasil wawancara dengan Hasan pada tanggal 13 Juli 2020);

4. "Pengaruh bagi saya akan berita hoaks adalah semakin sulit untuk memilih mana berita yang sesuai fakta dan mana yang palsu." (Hasil wawancara dengan Naila pada tanggal 13 juli 2020); 
5. "Sebagai pengalihan isu. Di media sosial ataupun internet khususnya para penjahat internet atau biasa dipanggil cyber crime, hoaks biasa dimanfaatkan sebagai pelancar aksi kejahatan mereka di internet atau di sosial media. Misalnya yang saya ketahui, pengiriman sebuah berita hoaks dari para penjahat cyber yang berisi telah terjadi kerentanan dalam sistem pelayanan internet seperti gmail dan e-mail." (Hasil wawancara dengan Dewi Informan hasil wawancara pada tanggal 13 Juli 2020:

6. "Yang saya ketahui ya cukup banyak, misalnya banyaknya pesan-pesan dan berita-berita terutama di media sosial Facebook yang dilanjutkan tanpa adanya rasa tanggung jawab akan kebohongan berita tersebut, padahal terkadang berita dan informasi yang disebarkan tersebut hoaks namun sebagian dari kita ada yang percaya juga, pengaruh bagi saya sangat merugikan sekali." (Hasil wawancara dengan Hidayati pada tanggal 14 Juli 2020):

"Pengaruh bagi saya akan berita hoaks adalah semakin sulit untuk memilih mana berita yang sesuai fakta dan mana yang palsu." (Hasil wawancara dengan Naila pada tanggal 13 juli 2020);

7. "Sebagai pengalihan isu. Di media sosial ataupun internet khususnya para penjahat internet atau biasa dipanggil cyber crime, hoaks biasa dimanfaatkan sebagai pelancar aksi kejahatan mereka di internet atau di sosial media. Misalnya yang saya ketahui, pengiriman sebuah berita hoaks dari para penjahat cyber yang berisi telah terjadi kerentanan dalam sistem pelayanan internet seperti gmail dan e-mail." (Hasil wawancara dengan Dewi Informan hasil wawancara pada tanggal 13 Juli 2020:

8. "Yang saya ketahui ya cukup banyak, misalnya banyaknya pesan-pesan dan berita-berita terutama di media sosial Facebook yang dilanjutkan tanpa adanya rasa tanggung jawab akan kebohongan berita tersebut, padahal terkadang berita dan informasi yang disebarkan tersebut hoaks namun sebagian dari kita ada yang percaya juga, pengaruh bagi saya sangat merugikan sekali." (Hasil wawancara dengan Hidayati pada tanggal 14 Juli 2020):

Dari beberapa hasil wawancara terhadap mahasiswa organisasi PMII tersebut, maka dapat dilihat bahwa peran mahasiswa organisasi PMII sebagai kaum terpelajar dengan tidak mudah tergiring oleh opini yang beredar di media sosial khususnya di Facebook. Agar tidak mudah percaya pada informasi yang sedang diperbincangkan di dunia maya. Sebab biasanya mahasiswa memiliki jiwa dan sikap yang kritis ketika 
melihat suatu persoalan menyimpang yang sedang terjadi disekitarnya. Tidak boleh apatis atau menerima informasi apa adanya tanpa menganalisis dan menelaah terlebih dahulu setiap berita yang dikonsumsi. Menjadi kewajiban bagi mahasiswa yang notabenenya sebagai generasi penerus bangsa, untuk membawa masyarakat menuju perubahan yang lebih baik. Sehingga menjadi kewajiban mahasiswa, khususnya mahasiswa yang aktif dalam organisasi Islam untuk membawa masyarakat menuju perubahan ke arah yang lebih baik. Sebab mahasiswa sebagai salah satu agen perubahan dan agen kontrol bagi masyarakat yang dapat memberikan suasana yang aman, tentram dan sejahtera bagi kehidupan masyarakat.

Penerapan Etika Komunikasi Islam Mahasiswa Organisasi PMII di Facebook

Dikalangan remaja, media sosial Facebook sangat diminati, terlihat dari antusias generasi muda yang sangat sering menggunakan jaringan sosial Facebook sebagai salah satu media komunikasi dengan temantemannya dan untuk mencari informasi. Sedangkan media sosial Facebook sebagai sarang penyebaran berita hoaks terbanyak. Pengguna Facebook rata-rata menghabiskan waktu setiap harinya untuk menuliskan informasi yang didapat di beranda, kemudian menyukai, mengomentari dan bahkan beberapa diantaranya membagikan atau menyebarkan sesuatu pada dinding
Facebook miliknya. Salah satu penikmat Facebook terbanyak ialah generasi muda. Ditakutkan akan merusak moral generasi muda yang sedang mangalami kondisi rentan. Begitupula para mahasiswa yang aktif dalam organisasi Islam PMII. Mereka menggunakan Facebook sebagai media komunikasi antar anggota.

Sebagaimana yang kita ketahui bahwa PMII merupakan organisasi mahasiswa berideologi Ahlussunnah Wal Jama'ah (Aswaja), yaitu kelompok yang menjalankan sunnah Rasulullah Saw dengan penekanan pada ajaran dan peneladanan peri kehidupan Nabi Muhammad Saw. Dituntut untuk mempunyai kecerdasan literasi digital yang tinggi, sehingga tidak mudah terpengaruh oleh berita serta informasi hoaks. Maka dari itu harus menanamkan suatu etika komunikasi di kehidupan sosial. Selain menanamkan suatu etika komunikasi di dunia nyata, haruslah ditanamkan juga di dunia maya. Dalam kehidupan sehari-hari etika biasa disebut dengan akhlak dan moral.

Berdasarkan hasil wawancara, mahasiswa PMII dalam media sosial Facebook selalu mengedepankan akhlak dan moral sesuai syari'at Islam yaitu dengan mengikuti teladan Rasulullah SAW. Karena Islam sebagai agama yang membawa rahmat dan memberikan petunjuk pada setiap umatnya dalam menjalankan kehidupan agar sesuai dengan tuntunan syari'at. Sebagai seorang muslim yang baik dalam konteks bermuamalah dengan orang 
lain di dunia nyata dan dunia maya misalnya, tidak diperbolehkan melakukan hal yang dapat merugikan orang lain. Sebaiknya, lebih berhatihati dalam menerima pemberitaan dan informasi di media sosial Facebook. Sebagai mahasiswa yang aktif dalam organisasi Islam dan mengetahui akan hukum Islam dilarang untuk suudzon karena dapat berujung pada fitnah.

Dalam bermedia sosial, sebaiknya bijak dalam menerima dan menyampaikan informasi.

Berdasarkan hasil wawancara dengan Thoriq, Hasan dan Dewi pada tanggal 13 Juli 2020 mereka menyampaikan bahwa mereka lebih membatasi diri dari hal-hal yang kurang bermanfaat. Ketika mereka membutuhkan informasi dari pemberitaan yang mereka dapatkan, maka mencari informasi terlebih dahulu dari sumber yang terpercaya (misal: akun resmi pemerintah). Sebab maraknya kasus pidana yang salah satunya dari menyebarkan berita hoaks, maka dari itu mereka lebih hati-hati dalam menggunakan media sosial agar tidak berujung pada penyesalan. Maka pendapat mahasiswa organisasi PMII pentingnya menerapkan etika komunikasi Islam dalam bermedia sosial Facebook.

Menerapkan etika komunikasi Islam dilakukan untuk mengirimkan informasi yang didapat melalui beranda Facebook yang belum jelas sumbernya, agar tidak saling menghina atau menuduh orang tanpa alasan yang jelas. Maka mahasiswa organisasi PMII selalu berusaha untuk menggunakan media sosial secara bijak, agar tidak terjerat hukum karena kurang hati-hati dalam menyaring dan menyebarkan informasi di internet. Salah satu mahasiswa organisasi PMII, dengan hasil wawancara Rika pada tanggal 13 Juli 2020, menuturkan bahwa:"Membiasakan hidup dengan baik, santun, tanpa keluar kata-kata kotor, dan hindari lingkungan yang kiranya di luar syariat islam. kalau belum bisa terus belajar belajar belajar."

Hasil wawancara dengan Naila pada tanggal 13 Juli 2020, ia menuturkan bahwa: "Alangkah lebih baiknya untuk tidak tergesa-gesa dalam menyebarluaskan berita yang baru didapat. Caranya adalah dengan mengembangkan kepekaan terhadap berita-berita yang didapat, tanamkan dalam diri untuk berkata yang benar, berkata tidak menyakitkan, dan berkata yang lembut. Harus tutur kata agar tidak menyakiti orang lain.”

Hasil wawancara dengan Thoriq pada tanggal 13 Juli 2020, ia menjelaskan bahwa "Ketika menyampaikan gagasan di media sosial khususnya di facebook harus sesuai dengan porsinya, sedang dengan siapa kita berkomunikasi. Sebab kita sebagai orang Islam harus mengetahui, bahwa agama Islam selalu mengajarkan agar menggunakan kata-kata yang mulia dan baik untuk sesama manusia."

Jika hasil wawancara dengan Dewi pada tanggal 13 Juli, menjelaskan bahwa: "Allah SWT telah mewanti-wanti umat Islam untuk tidak gegabah dalam 
membenarkan suatu berita yang disampaikan oleh kaum fasik. Kita dituntut agar lebih berhati-hati dalam menerima pemberitaan dari media apapun termasuk Facebook media yang sering saya gunakan. Terlebih media sekarang banyaknya berisi dengan ujaran kebencian dan berita hoaks kepada pihak lain. Padahal Islam sebagai agama yang membawa rahmat bagi alam semesta telah memberikan petunjuk kepada umatnya dalam menjalankan kehidupannya agar sesuai dengan tuntutan syariat. Agar terhindar dari berita hoaks, pertama qawlan ma'ruf (berkata yang baik). Sebab perkataan jenis ini identic dengan kesantunan dan kerendahan hati. Kedua, qawlan tsabit (ucapan yang teguh). Perkataan ini mempunyai argumentasi yang kuat serta dilandasi dengan keimanan yang kokoh. Dan ketiga, qawlan sadid (perkataan yang benar). Tiada dusta dan kebatilan dalam ucapan ini."

Melalui wadah mahasiswa PMII diharapkan mampu memberikan contoh bahwa pentingnya beretika dalam menggunakan media sosial, khususnya Facebook. Etika dalam Islam tidak dapat dilepaskan dengan ilmu akhlak. Mahasiswa dapat dijadikan sarana untuk memberikan edukasi kepada masyarakat tentang etika komunikasi di dunia maya yang sesuai dengan ajaran Islam. Etika dapat mengarahkan perilaku saat berkomunikasi secara santun, jujur dan tidak merugikan orang lain. Hal ini dapat menjadi perisai dalam menghindari penyebaran informasi hoaks.
Dalam menyikapi fenomena hoaks yang santer dibicarakan saat ini para mahasiswa organisasi PMII

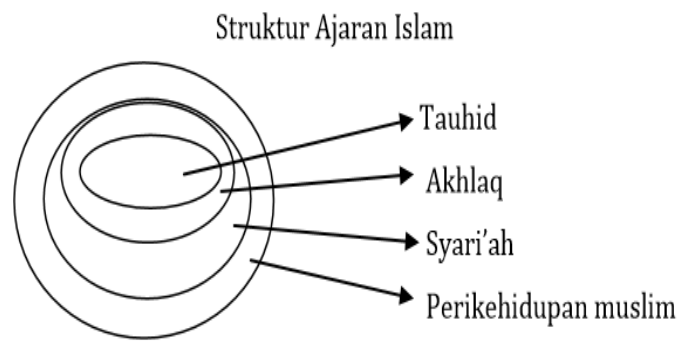
menggunakan media sosial Facebook lebih bijak dengan menerapkan etika dan mengedepankan akhlakul karimah sesuai syari'at Islam agar terhindar dari informasi-informasi hoaks. Jika akhlak atau etika dalam struktur ajaran Islam menurut Hamka dapat digambarkan sebagai berikut: (Haris, 2010).

Akhlak atau etika dalam ajaran agama Islam telah menempati pada urutan kedua setelah ajaran inti tauhid. Artinya akhlak harus selalu dijiwai oleh ajaran tauhid. Sedangkan syari'ah menjadi urutan ketiga dari ajaran inti, tauhid, setela akhlak sebagai ajaran Islam. Berarti dalam Islam sebuah syari'ah harus selalu dijiwai dengan tauhid dan akhlak. Kurang tepat jika syari'at dan pelaksanaannya keluar dari kerangka dan ajaran tauhid dan akhlak. Harus ada ikatan sesuai dengan syari'at Islam, atas segala permasalahan dan kebebasan yang ada. Syari'at Islam harus bertumpu pada ajaran akhlak Islam. Sedangkan akhlak atau etika Islam harus bertumpu pada ajaran tauhid dalam Islam (Haris, 2010).

Pentingnya dalam melakukan sosialisasi mengedepankan akhlak dan etika sesuai dengan ajaran 
syari'at Islam, karena pada dasarnya masyarakat tidak bisa terlepas dari sosialisasi. Menurut Larry A. Samovar menyatakan dengan istilah "we can't not communication" yang berarti kita tidak dapat tidak berkomunikasi. Manusia tidak akan lepas dari interaksi kepada sesama, sehingga dalam Islam juga ditetapkan aturan main (kaifiyah) dalam berkomunikasi yang sudah dicantumkan dalam ayat Al-Qur'an dan Hadis Nabi., Al-Qur'an diturunkan kepada umat manusia yang memiliki sifat sebagai makhluk yang memerlukan komunikasi, sehingga Al-Qur'an memberikan tuntunan komunikasi kepada manusia, menurut Hasnas dalam berkomunikasi, Islam menekankan pada nilai sosial, religius dan budaya (Mannan, 2019). Selain itu, hoaks merupakan fitnah yang keji. Dalam agama juga dilarang untuk memfitnah seseorang, fitnah dianggap lebih kejam daripada pembunuhan. Apabila dilihat, fenomena hoaks ini akan mengganggu korban dalam hidupnya sehingga akan megganggu haknya untuk hidup aman dan nyaman. Pelanggaran terhadap hak hidup seseorang termasuk pelanggaran Hak Asasi Manusia (HAM) (Rufaida et al., 2020).

Komunikasi dalam Islam merupakan kegiatan dakwah dan aktivitas utama pribadi muslim. Hal tersebut tercermin dari perilaku dan tugas Rasulullah Saw sebagai pemberi informasi yang bermanfaat bagi kehidupan manusia sehingga melalui kegiatan tersebut terbentuk kondisi sosial yang melaksanakan ammar ma'ruf nahi munkar untuk mewujudkan akhlak pada masyarakat yang Islami, sebagai etika dan kearifan sosial yang diidamkan. Etika menjadi sesuatu yang sangat penting ketika proses komunikasi berjalan, sehingga yang menentukan berbobot tidaknya alur komunikasi adalah etika komunikasi. Jadi komunikasi yang diiringi dengan adab, kepatuhan dan keluhuran yang membingkainya adalah etika komunikasi (Taufik, 2012).

Suatu etika komunikasi Islam yang dipaparkan oleh Jalaluddin Rakhmat terdapat enam bentuk atau jenis gaya bicara (qawlan) yang dijadikan sebagai kaidah, prinsip atau etika komunikasi Islam di dalam AlQur'an adalah Qawlan Sadidan (perkataan yang benar, jujur atau lurus), Qawlan Balighan (perkataan yang mudah dimengerti), Qawlan Maysuran (perkataan yang ringan), Qawlan Layyinan (perkataan lemah lembut), Qawlan Kariman (perkataan yang mulia), Qawlan Ma'rufan (perkataan yang baik) (J. Rakhmat, 1994). Sebagai contohnya, bahwa Allah memerintahkan ketika berkomunikasi agar menerapkan qawlan sadida sesudah taqwa, seperti yang tertera dalam FirmanNya QS. Al-Ahzab ayat 70): "Wahai orangorang yang beriman! Diwajibkan atas kalian untuk bertaqwa kepada Allah dan ucapkanlah perkataan yang benar" (Kementerian Agama RI, 2011).

Prinsip komunikasi menurut AlQur'an adalah berkata yang benar. 
Ada beberapa makna dari pengertian yang benar:

1. Sesuai dengan kriteria kebenaran

2. Tidak bohong

Arti kedua dari qawlan sadida adalah ucapan yang jujur, tidak bohong dapat diwujudkan dengan menjaga lisan. Nabi muhammad Saw bersabda: Dari Abu Juhaifa, Rasulullah Saw bertanya: "Amal apa yang paling disukai Allah? Para sahabat terdiam. Tidak seorangpun menjawab. Dengan sendirinya Beliau bersabda; Baiknya jagalah Lisan kalian." (Alaik, 2011). Prinsip di atas sama seperti dengan penuturan Rika hasil wawancara pada tanggal 13 Juli 2020: "Kalau tidak ada dasar bukti yang nyata lalu carilah hal yang mendasari berita tersebut, jika tak mau mencari kepastiannya lebih baik diam dan abaikan."

Semua proses komunikasi yang Islami harus terikat pada normanorma agama Islam, dengan kata lain komunikasi menurut ajaran Islam sangat memuliakan etika yang dibarengi oleh sanksi akhirat (Muis, 2001). Demikian dalam etika komunikasi sangatlah dianjurkan dalam Islam. Karena sudah tertera dalam ayat Al-Qur'an dan Hadis bahwa kebaikan atau perilaku seseorang dapat dilihat dari cara beretika dalam berkomunikasi, maka Islam tidak lepas dari etika komunikasi sesuai dengan ajaran syari'at Islam.

\section{Kesimpulan}

Peran mahasiswa organisasi PMII sebagai kaum terpelajar dengan tidak mudah tergiring oleh opini yang beredar di media sosial khususnya di Facebook. Agar tidak mudah percaya pada informasi yang sedang diperbincangkan di masyarakat. Sebab mahasiswa memiliki sikap kritis dalam melihat setiap persoalan yang terjadi di sekelilingnya. Tidak boleh apatis atau menerima informasi apa adanya tanpa menganalisis dan menelaah terlebih dahulu setiap berita yang dikonsumsi. Sudah dibekali ilmu jadi kewajiban bagi mahasiswa salah satunya adalah membawa masyarakat menuju perubahan agar yang lebih baik. Sehingga menjadi kewajiban mahasiswa, khususnya mahasiswa yang aktif dalam organisasi Islam untuk membawa masyarakat menuju perubahan ke arah yang lebih baik. Sebab mahasiswa sebagai salah satu agen perubahan dan agen kontrol bagi masyarakat yang dapat memberikan suasana yang aman, tentram dan sejahtera bagi kehidupan masyarakat.

Prinsip komunikasi sesuai dengan syari'at Islam menurut mahasiswa organisasi PMII berkata jujur dan benar, sesuai dengan kriteria kebenaran dan tidak bohong. Semua proses komunikasi yang Islami harus terikat pada norma-norma agama Islam, dengan kata lain komunikasi menurut ajaran Islam sangat memuliakan etika yang dibarengi oleh sanksi akhirat. Demikian dalam etika 
komunikasi sangatlah dianjurkan dalam Islam.

\section{Referensi}

Afriani, F., \& Azmi, A. (2020). Penerapan Etika Komunikasi di Media Sosial: Analisis Pada Grup WhatsApps Mahasiswa PPKn Tahun Masuk 2016 Fakultas Ilmu Sosial Universitas Negeri Padang. 3(3), 331-338.

Alaik, S. (2011). 40 Hadits Shahih Bibirmu Harimaumu (ke-1). Pustaka Pesantren.

Ali, H., Purwandi, L., \& Nahrawi, I. (fw. . (2017). Millennial Nusantara: pahami karakternya, rebut simpatinya. Gramedia Pustaka Utama.

Ariani, A. (2015). Standarisasi dan Dasar Pijakan Etika Komunikasi Dakwah. 14(28), 49-62.

Erni R. Ernawan. (2011). Business Ethics. Alfabeta.

Fatkhurahman. (2018). Kemampuan Mahasiswa Tempatan Menilai Berita Palsu Atau "Hoax" Dalam Media Sosial Dalam Upaya Pengembangan Jiwa Kewirausahaan. Jurnal Benefita, 3(3), 417. https://doi.org/10.22216/jbe.v3i3. 3036

Haris, A. (2010). Etika Hamka ; Konstruksi Etik Berbasis Rasional-Religius. LkiS.

Juditha, C. (2018). Hoax Communication Interactivity in Social Media and Anticipation (Interaksi Komunikasi Hoax di Media Sosial serta Antisipasinya). Journal Pekommas, 3(1), 31. https://doi.org/10.30818/jpkm.20 18.2030104

Kementerian Agama RI. (2011). AlQur'an dan Terjemahnya.
Penerbit Jumanatul 'Ali-Art (JART).

Kholil, S. (2007). Komunikasi Islam (ke-1). Cipta Pustaka Media.

Mannan, A. (2019). Etika Komunikasi Interpersonal Mahasiswa Ilmu. Jurnal Aqidah, 5.

Mastel. (2019). Hasil Survey Wabah Hoax Nasional 2019. Website Masyarakat Telematika Indonesia, 35. https://mastel.id/hasil-surveywabah-hoax-nasional-2019/

Maulana, L. (2017). Kitab Suci dan Hoax: Pandangan Alquran dalam Menyikapi Berita Bohong. Wawasan: Jurnal Ilmiah Agama Dan Sosial Budaya, 2(2), 209222.

https://doi.org/10.15575/jw.v2i2. 1678

Taher, M.S. (2019). Pendidikan Etika Budaya Komunikasi Melalui Media Sosial Berbasis Al- Qur, An Pascasarjana Institut PTIQ Jakarta Mahasiswa Pascasarjana Institut PTIQ Jakarta. Journal of Islamic Educatioan |, 47-72.

Muis, A. A. (2001). Komunikasi Islam. Remaja Rosdakarya.

Muslimah. (2016). Etika komunikasi dalam persfektif islam. 13(2).

Mutiah, T., Albar, I., Fitriyanto, \& A.Rafiq. (2019). Etika Komunikasi Dalam Menggunakan Media Sosial. Global Komunika, 1(1), 14-24. https://core.ac.uk/download/pdf/2 87201763.pdf

Oxford University Press. (2011). Oxford Learner's Pocket Dictionary (ke-4). Oxford University Press.

Prasanti, D., \& Indriani, S. S. (2017). Etika Komunikasi Dalam Media Sosial Bagi Ibu- Ibu Pkk Di Desa Mekarmukti Kab.Bandung Barat 
(Studi Deskriptif Kualitatif tentang Etika Komunikasi dalam Media Sosial bagi Ibu-Ibu PKK di desa Mekarmukti Kab.Bandung Barat). Profetik: Jurnal Komunikasi, 10(1), 21. https://doi.org/10.14421/pjk.v10i 1.1219

Purnama, S. G. (2017). Etika dan hukum kesehatan Sang Gede Purnama , SKM , MSc Program Studi Ilmu Kesehatan Masyarakat Fakultas Kedokteran Universitas Udayana. September.

Rakhmat, J. (1994). Islam Aktual Refleksi Seorang Cendekiawan Muslim. Mizan.

Rakhmat, M. (2013). Etika Dasar Setiap Profesi Kehidupan dalam Perspektif Hukum Positif. 1-95.

Rufaida, K. K., Handitya, B., \& Sucipto, R. (2020). Penerapan “ ISA " ( Internet Sehat dan Aman ) Sebagai Upaya Menghindari. 176-186.

Septanto, H. (2018). Pengaruh Hoax dan Ujaran Kebencian Sebuah Cyber Crime dengan Teknologi Sederhana di Kehidupan Sosial Masyarakat. Jurnal Sains Dan Teknologi, 5(2), 157-162.

Soyomukti, N. (2010). Pengantar Ilmu Komunikasi. Ar-Ruzz Media.

Taufik, T. (2012). Buku Etika Komunikasi Islam (ke-1). Pustaka Setia.

Ulya, U. (2018). Post-Truth, Hoax, dan Religiusitas di Media Sosial. Fikrah, 6(2), 283. https://doi.org/10.21043/fikrah.v6 i2.4070

Walidah, I. Al. (2018). Tabayyun di Era Generasi Millenial. Jurnal Living Hadis, 2(2), 317. https://doi.org/10.14421/livingha dis.2017.1359
Sumber Lain:

Kusnandar, V.B., 25/9/2019, 11.00 WIB, Indonesia, Negara dengan Penduduk Muslim Terbesar di Dunia, Dikutip dari https://databoks.katadata.co.id/da tapublish/2019/09/25/indonesianegara-dengan-pendudukmuslim-terbesar-dunia).

Eka, R. 16/8/2018, Facebook, WhatsApp, dan Instagram adalah Platform yang paling digunakan untuk Menyebar Hoax, Dikutip dari https://dailysocial.id/post/laporan -dailysocial-distribusi-hoax-dimedia-sosial-2018).

Pertiwi, W. K., Kominfo Identifikasi 54 Hoaks Virus Corona, Penyebar Bisa Dijerat UU ITE, 03/02/2020, 13:39 WIB, Dikutip dari

https://tekno.kompas.com/read/2 020/02/03/13394877/kominfoidentifikasi-54-hoaks-viruscorona-penyebar-bisa-dijerat-uuite?page $=$ all). 